\title{
Taloudelliset kannusteet toimivan eläintautiriskien hallinnan edellytys
}

\author{
Jarkko K. Niemi ja Kyösti Pietola \\ Maa- ja elintarviketalouden tutkimuskeskus, taloustutkimus, Luutnantintie 13, 00410 Helsinki, \\ etunimi.sukunimi@mtt.fi
}

\section{Johdanto}

Kotieläintuottaja on avainasemassa torjuttaessa eläintauteja, sillä hän voi omalla toiminnallaan estää niiden leviämistä tilalleen tai pois tilalta. Tarttuvien eläintautien torjunnassa onkin tärkeää, että kaikilla tuottajilla on taloudellinen kannustin toimia taudin leviämistä estävällä tavalla. Tehokkaita keinoja estää tarttuvien eläintautien leviäminen ovat taudin leviämisreittien ja niiden välityksellä siirtyvän taudinaiheuttajan määrän minimointi. Lisäksi erityisesti herkästi leviävien eläintautien esiintyminen on tärkeää havaita ajoissa eläinten oireilua (joka voi ilmetä viikkoja infektion jälkeen) tarkkailemalla.

Herkästi leviävien tarttuvien eläintautien aiheuttamat suorat vahingot korvataan Suomessa valtion varoista. Tartunnan epäsuorat vaikutukset, kuten eläimen teurastuksen viivästyminen ja siitä aiheutuva tuotteen laadun aleneminen tai tuotannon keskeytys voivat kuitenkin aiheuttaa kotieläintiloille mittavia taloudellisia vahinkoja, jotka voivat jäädä kokonaan tai osittain tuottajan maksettavaksi. Tällaiset tulonmenetykset aiheutuvat lähinnä tuotantopäätöksiin liittyvästä ajallisuuskustannuksesta ja tuotantopotentiaalin menetyksestä (Huirne ym. 1993). Sianlihan tuottaja voikin joutua tilanteeseen, jossa taloudelliset kannustimet ohjaavat häntä valitsemaan tautiriskiä lisääviä toimintavaihtoehtoja.

Tuottajan ja eläinlääkärin kannustimet voivat vaikuttaa korkean riskin periodin pituuteen. Kynnys epäillä herkästi leviävää eläintautia voi nimittäin olla korkea, jos alueella ei ole viitteitä taudista. Ongelma johtuu siitä, että herkästi leviävän eläintaudin epäileminen rajoittaa tilan toimintaa ja voi estää esimerkiksi teuraskypsien sikojen kuljettamisen teuraaksi vähintäänkin muutaman päivän ajaksi aiheuttaen siten tulonmenetyksiä. Lisäksi herkästi leviävät eläintaudit voivat aiheuttaa sikaloissa usein tavattavia sairauksia muistuttavia oireita, joten epävarmassa päätöksentekotilanteessa päätös epäillä herkästi leviävāä eläintautia voi viivästyä ja infektio voi levitä melko vapaasti entistä useammalle tilalle.

Euroopassa havaittujen eläintautiepidemioiden mukaan (mm. Mangen 2002) merkittävä tautipolitiikan kannustinongelma on ollut se, että tuottajat ovat voivat nopeasti reagoimalla hyödyntää taudin leviämistä estävistä toimenpiteistä saatua informaatiota ja kuljettaa eläimet pois "rajoitusuhan" alta minimoidakseen tulonmenetyksensä. Tällainen toiminta on lisännyt taudin leviämisriskiä, sillä eläinkuljetus on tarjonnut reitin, jonka välityksellä taudinaiheuttaja on voinut levitä taudista vapaalle tilalle. Siten tulonmenetysten korvaamatta jättäminen voi heijastua taudin leviämisenä entistä useammalle tilalle siitäkin huolimatta, että eläinten kuljettaminen pois tautiriskialueelta on eläintautilainsäädännön mukaan ehdottomasti kiellettyä (MMM 1980, MMM 1960). Suomessa käytäntönä on ollut korvata viranomaisten toimenpiteiden aiheuttamat merkittävät tulonmenetykset. Korvaaminen muun kuin viranomaisten määräyksestä hävitetyn omaisuuden osalta on kuitenkin harkinnanvaraista, joten käytäntö voi aiheuttaa kannustinongelmia. Toinen taudin leviämiseen liittyvä kannustinongelma on, että tautitilanteen pitkittyminen voi alentaa tuottajan motivaatiota ylläpitää tilan tautisuojausta tai lisätä hänen motivaatiotaan teurastuttaa siat etenkin, jos tautirajoitukset aiheuttavat merkittäviä taloudellisia vahinkoja ja eläinten infektoituminen tai teurastaminen on hetkellisesti ainoa keino päästä tilanteesta pois.

Tämän tutkimuksen tavoitteena on tuottaa tietoa sikojen teurastusta ja uusien porsaiden hankintaa rajoittavien määräysten sianlihan tuottajalle aiheuttamista taloudellisista menetyksistä, ja arvioida tuottajan taloudellisia kannustimia joko teurastuttaa siat ennenaikaisesti tai ruokkia niitä, kun hän epäilee tilan joutuvan rajoittavien määräysten alaiseksi. Tutkimuksessa kehitetään dynaamisen ohjelmoinnin malli, jolla arvotetaan teurastusajankohdan muuttumisesta ja tyhjästä tuotantokapasiteetista tuottajalle aiheutuva tulonmenetys. Mallissa tuottaja valitsee optimaalisen energia ja valkuaisrehuruokinnan ja teurastusajankohdan, mikäli teurastusta ei ole rajoitettu. Lisäksi malli ottaa huomioon teurastuksen viivästymisestä aiheutuvan ruhon arvon alenemisen (lihan laatuhinnoittelu) ja kasvaneesta sikalan eläintiheydestä aiheutuvat laatu- ja kuolleisuustappiot. Tuloksia tarkastellaan eläimen painon ja rajoitusten keston mukaisissa skenaarioissa.

\section{Aineisto ja menetelmät}

Tutkimuksessa kehitettiin dynaamisen ohjelmoinnin malli, jolla simuloitiin sian kasvua ja sianlihantuottajan tulovirtoja rajoittavien määräysten aiheuttamassa tilanteessa. Teurastuspäätöksen rajoittaminen voi alentaa 
ruhon arvoa esimerkiksi siten, että teurastuksen viivästyessä tavanomaisesta optimista ruho rasvoittuu ja lihan sianlihan tuottajahinta laskee. Mallissa sian elopaino jaettiin rasvaiseen ja rasvattomaan kudokseen. Lisäksi ruokinta jaettiin energia- ja valkuaispitoiseen rehuun (ohra ja soija) (vrt. Pietola ja Sévon-Aimonen 2002). Näin saatiin hinnoiteltua normaalista poikkeavan teurastushetken sianlihantuottajalle aiheuttama tulonmenetys. Sian kasvun mallinnettiin rasvaisen ja rasvattoman kudoskomponentin kasvuna siten, että elintoimintojen ylläpitoon käytetyn energia- ja valkuaisrehu on käytettävissä uuden kudoksen synteesiin eli kasvuun. Lisäksi kasvua mallinnettaessa otettiin huomioon kudoskomponenttien keskinäinen yhteys. Siirtymäyhtälö sian kudoskomponentille $\left(x_{t}\right)$ hetkestä $t$ hetkeen $t+1$ noudatti Compertz-funktiota seuraavasti:

$$
x_{t+1}=f\left(x_{t}, u_{t}\right) \text {, }
$$

jossa $x_{t}$ mittaa kudoskomponentin määrää hetkellä $t$ ja $u_{t}$ ilmaisee teurastus- ja ruokintapäätöksen vaikutuksen kudoskomponentin kasvuun. Mallissa tuottaja ratkaisee samanaikaisesti annetuille hintasuhteille optimaalisen sian ruokinnan ja teurastusajankohdan. Tuottaja voi valita joko rajoitetun tai vapaan ruokinnan. Vapaassa ruokinnassa sian kasvu määräytyy sen luontaisen kasvupotentiaalin mukaan. Sekä ruokinta- että teurastuspäätös vaikuttavat ruhon laatuun.

Sikapaikan arvo mallinnettiin stokastisella dynaamisella ohjelmoinnilla. Tuottajan tavoitteena oli maksimoida sikapaikan arvo suunnitteluperiodilla $(t=[0, T])$, joka alkoi rajoittavien määräysten antamishetkestä. Tavoitefunktion arvo maksimoitiin iteroimalla Bellmannin yhtälöä (Bellman 1957):

$$
\begin{gathered}
V_{t}\left(x_{t}\right)=\max { }_{\left\{u_{t}^{s}, u_{t}^{f}\right\}_{t=0}^{T}}\left\{R_{t}+\beta E\left[V_{t+1}\left(x_{t+1}\right)\right]\right\} \\
\text { s.t. (1) ja } x_{0} \text { annettu, }
\end{gathered}
$$

jossa $x_{t}$ kuvaa tilannemuuttujan arvoa, $\beta$ on diskonttaustekijä, $u_{t}^{f}$ ilmaisee ruokinnassa käytettyjen rehujen määrän ja $u_{t}^{s}$ ilmaisee teurastusmuuttujan arvon, $R_{t}$ on yhden periodin tulovirta, $V_{t+l}\left(x_{t+1}\right)$ on odotusarvo seuraavan periodin arvofunktiolle. Arvofunktiota rajoittaa tilannemuuttujan siirtymäyhtälö (yhtälö 1) ja tilannemuuttujan lähtöarvo $\left(x_{0}\right)$ iteroinnin alkamishetkellä. Maksimointiongelma ratkaistiin rekursiivisesti jokaiselle tilannemuuttujan arvolle edeten viimeisestä periodista $(t=T)$ ensimmäiseen periodiin $(t=0)$ ja sen jälkeen sijoittamalla annettu tilannemuuttujan lähtöarvo $\left(x_{0}\right)$ ratkaisuun.

Yhden periodin tulovirta muodostuu ruokintakustannuksesta, mikäli sikaa ei teurasteta, ja lihan myyntituotosta, teuraspalkkiosta ja uuden porsaan hankintakustannuksesta, jos sika teurastetaan. Kun tilalle on annettu rajoittavat määräykset, teurastus ja uuden porsaan hankinta on kielletty siihen asti, kunnes rajoittavat määräykset poistetaan. Siten teurastetun sian paikka on tyhjillään rajoitusjakson ajan ja sian arvo rajoitusten alkamishetkellä määrää teurastuksen antaman tuoton. Jos eläimet kasvatetaan tavanomaista teuraspainoa suuremmiksi, tuottaja kärsii menetyksiä lisääntyneen kuolleisuuden, alentuneen rehuhyötysuhteen (Heikkonen 1998) ja ruhohylkäysten vuoksi (Tuovinen 1993).

Rajoitusskenaarioita simuloitiin eri painoisilla sioille. Rajoittavien määräysten aiheuttama tulonmenetys laskettiin vähentämällä rajoitetun toiminnan arvofunktio normaalin toiminnan arvofunktiosta. Lisäksi simuloitiin eri pituisia rajoitusjaksoja. Jokaiseen skenaarioon liittyi vaihtelevan pituinen varmuudella toteutuva rajoitusjakso. Tämän jälkeen tilan rajoittavat määräykset poistuivat päivänä $t$ todennäköisyydellä $p$ (skenaariosta riippuen $p=[0,1]$ ). Lisäksi kaikki skenaariot simuloitiin siten, että rajoitusjakson edellä tuottaja voi joko teurastuttaa siat ja pitää sikapaikan tyhjillään tai kasvattaa siat ylipainoisiksi rajoitusten alla. Rajoittavien määräysten poistamisen jälkeen tuottajan oletettiin noudattavan samaa ruokinta- ja teurastuspolitiikkaa kuin ennen rajoitusjakson alkamista. Kasvupotentiaali perustui Sevón-Aimosen (2001) koejärjetelyihin. Muut parametrit johdettiin kirjallisuudesta tai tilastoista (parametritiedot on saatavissa kirjoittajilta). Simuloinneissa käytettiin vuosien 2001-2002 hintasuhteita.

\section{Tulokset ja tulosten tarkastelu}

Tulosten mukaan tuottaja minimoi rajoittavista määräyksistä aiheutuvia tappioita rajoittamalla lihasian energiaruokintaa. Valkuaisen tarve tyydytettiin säätelemällä soijan määrää dieetissä sekä korvaamalla soijaa tarvittaessa aminohappolisäyksellä. Näin tuottaja voi ylläpitää ruhon laatua mahdollisimman pitkään. Ruokinnan rajoittaminen oli voimakkaampaa kun odotettavissa oli pitkä rajoitusjakso kuin jos odotettavissa 
oli lyhyt rajoitusjakso. Lisäksi sian elopaino rajoitusten määräämishetkellä vaikutti ruokinnan rajoittamiseen. Kun esimerkiksi elopainoltaan $109 \mathrm{~kg}$ painoiselle sialle (noin viikko ennen optimaalista teurastusta) määrättiin kiinteä 45 päivän rajoitusjakso, aleni ohran määrä päivittäisessä rehuannoksessa rajoitusjakson alussa noin 3 kilosta runsaaseen 2,5 kiloon. Saman pituisen rajoitusjakson määrääminen 89 kg painoiselle sialle laski ohran määrän rehuannoksessa noin 2,8 kilosta vajaaseen 2,4 kiloon päivässä. Samalla soijan määrä rehuannoksessa muuttui hieman.

Ylläpitoruokinnasta aiheutuva tulonmenetys oli sitä suurempi mitä lähempänä teurastushetkeä rajoitukset määrättiin tai mitä pitempi rajoitusjakson odotettu kesto oli. Toisaalta ennenaikainen teurastaminen aiheutti sitä suuremman tulonmenetyksen mitä nuoremmalle sialle se suoritettiin. Tämä johtui siitä, että odotettu tulonmenetys kasvoi teurastushetken siirtyessä kauemmaksi normaalisti optimaalisesta teurastushetkestä. Teurastuspäätöksen tuottajalle aiheuttama tulonmenetys oli pienempi kuin ylläpitoruokinnan aiheuttama tulonmenetys, jos rajoitusjakson odotettu kesto oli riittävän pitkä. Siten tuottajalla oli kannustin toimia taudin leviämistä estävällä tavalla lyhyellä rajoitusjaksolla.

Kun sian teurastus viivästyi neljä päivää tavanomaisesta teurastusajankohdasta, tuottaja kärsi runsaan euron tappion. Kun tilalle jolla oli elopainoltaan 109 kiloisia lihasikoja annettiin rajoittavat määräykset, joiden odotettu kesto on 31-59 päivää, tuottaja menetti 16,0-52,9 $€$ tulon sikapaikkaa kohti. Tilalla jolla oli elopainoltaan $89 \mathrm{~kg}$ lihasikoja määrättynä vastaava rajoitusjakso aiheutti 1,2-19,2€ menetyksen. Sian kasvattamisen vaihtoehtona tarkasteltiin tilannetta, jossa sika teurastettiin ennakoivasti mutta sikapaikka pidettiin tyhjillään kunnes rajoitukset poistetaan. Tässä tapauksessa tuottaja kärsi 10,1-17,9 € tulonmenetyksen, kun rajoittavat määräykset annettiin tilalle, jolla on $109 \mathrm{~kg}$ sikoja ja 17,6-25,4 € menetyksen, kun rajoitukset määrätään tilalle, jolla $89 \mathrm{~kg}$ sikoja. Yhden päivän tyhjä tuotantokapasiteetti aiheutti siten noin $0.38 €$ tulonmenetyksen.

Rajoitusten päättymisajankohdan muuttuessa stokastiseksi edellä mainittujen teurastusvaihtoehtojen aiheuttamat vahingot vaihtelivat välillä $22,1-47,4 €$ (89 kg sika) ja 38,4-40,7 € (109 kg sika) riippuen siitä, mikä oli rajoittavien määräysten minimikesto ja päättymistodennäköisyys minimikeston jälkeen (riippuvat määräysten syystä ja tilan sijainnista). Vastaavasti sian ylläpitoruokinnasta aiheutuvat menetykset olivat 5,5-26,2€ (89 kg sika) ja 23,8-53,7€ (109 kg sika). Taulukossa 1 on esitetty tuloksia $109 \mathrm{~kg}$ sialle.

Taulukko 1. Lihasian tuottajan tulonmenetys (€/sikapaikka) rajoittavien määräysten aiheuttamasta ylläpitoruokinnasta tai tuotantokapasiteetin pitämisestä tyhjillään, kun rajoitusten kohteena on elopainoltaan $109 \mathrm{~kg}$ lihasika. Rajoitusjakson odotettu kesto on tunnettu, tai sillä on lyhyt minimikesto (Rl, 21 vrk) tai pitkä minimikesto $(R 2,44$ vrk), jonka jälkeen rajoittavat määräykset poistetaan hetkellä $t$ todennäköisyydellä $p$.

\begin{tabular}{llccc}
\hline & & \multicolumn{3}{c}{ Odotusarvo rajoitusjakson kestolle } \\
Skenaario & Rajoitusjakson kesto & 31 & 45 & 59 \\
\hline Ylläpitoruokinta & tunnettu & 16,0 & 45,9 & 52,9 \\
Ylläpitoruokinta & R1 & 23,8 & 37,2 & 42,5 \\
Ylläpitoruokinta & R2 & - & 42,4 & 53,7 \\
Tyhjä tuotantokapasiteetti & tunnettu & 10,1 & 14,1 & 17,9 \\
Tyhjä tuotantokapasiteetti & R1 & 38,2 & 40,1 & 40,7 \\
Tyhjä tuotantokapasiteetti & R2 & - & 37,2 & 9,9 \\
\hline
\end{tabular}

\section{Johtopäätökset}

Tulosten mukaan tuottajalla on paremmat mahdollisuudet sopeutua rajoiteshokkiin silloin, kun tilalla on nuoria sikoja. Rajoittavien määräysten antaminen nuorelle sialle aiheuttaakin pienemmän menetyksen kuin teurastuksen rajoittaminen myyntikuntoisella sialla. Tällä voi olla vaikutuksia myös eläinten hyvinvointiin, sillä tuottajalla voi olla kannustin sopeuttaa teuraskypsän eläimen ruokintaa voimakkaastikin. Eläintautilain mukaan eläimen kuljettaminen alueelta, jossa epäillään tarttuvaa eläintautia, on kiellettyä. Tulosten mukaan näyttää kuitenkin siltä, että sianlihan tuottajan tappiot minimoituvat kun hän toimittaa lähes myyntikuntoiset siat tautiriskialueen ulkopuolelle. Tulos pätee silloin, kun rajoitusjakso voi pitkittyä. Lähes teuraskypsällä sialla mahdollinen ennenaikainen teurastus aiheuttaa nimittäin pienehkön menetyksen mutta voi auttaa tuottajaa välttämään suuren taloudellisen menetyksen. Eläintautiriskien hallinnan tehokkuuden kannalta onkin tärkeää, että tuottajalle ei synny taloudellista kannustinta teurastuttaa eläimiä ennenaikaisesti. Suomessa noudatettu korvauskäytäntö helposti leviävien eläintautivahinkojen korvaamisesta vähentää tällaisia kannustinongelmia, jos korvausperusteista sovitaan etukäteen. 
Haitallisten kannustinongelmien syntyminen voidaan estää etukäteen sopimalla tautivahinkojen korvauskäytännöistä ja korvausten ehdoista jo ennen kuin maassa on havaittu tautia. Tulosten mukaan korvausperusteissa tulisi ottaa huomioon kotieläimen tai siitä saatavan tuotteen laadun heikkenemisen, sekä ylläpitoruokinnasta aiheutuvat kustannukset. Käytännössä tämä voitaisiin tehdä esimerkiksi niin, että tuottajilla olisi tarjolla etukäteen sovittu mahdollisuus myydä eläimensä ("teurastus taloudellisista syistä") rajoitusten poistamisen jälkeen kompensaatiolla, joka olisi vähintään yhtä korkea kuin tyhjän tuotantokapasiteetin aiheuttama tulon menetys.

Tulokset viittaavat myös siihen, että tarttuvien eläintautien havaitsemista voidaan tehostaa siirtämällä tuottajien mahdollisista tautiepäilyistä kärsimä vahinko koko sikasektorin kannettavaksi. Näin yksittäisellä tuottajalla ja eläinlääkärillä olisi kannustimet tutkituttaa eläimet epäilyttävissä tapauksissa esimerkiksi klassisen sikaruton tai suu- ja sorkkataudin varalta jo nykyistä aikaisemmin, koska lyhyestäkin teurastuksen viivästymisestä aiheutuva haitta olisi tällöin vältettävissä. Analyysi ei kuitenkaan anna suoraan tietoa siitä, missä tapauksissa riskin siirtäminen olisi sikasektorin tai yhteiskunnan kannalta taloudellisesti tehokasta. Eläintaudin havaitsemistehon lisääntymisellä yhteiskunnan saavuttamia nettohyötyjä arvioitaessa merkitystä on myös sillä, mihin tarkoitukseen rajoitusten alla olleesta eläimestä saatu tuote voidaan käyttää, miten paljon kustannuksia uusien tautitapausten hävittämisestä aiheutuu ja miten paljon uusien tautitapausten esiintymisriskiä voidaan alentaa kannustinongelmat poistamalla ja mitä erityisvaatimuksia taloudelliset teurastukset epidemian aikana vaatisivat.

\section{Kirjallisuus}

Bellmann, R. (1957) Dynamic Programming. Princeton University Press, New Jersey. 339 p.

Huirne, R.B.M., Dijkhuizen, A.A., van Beek, P. \& Hendriks, Th.H.B. 1993. Stochastic dynamic programming to support sow replacement decisions. Eur. J. Oper. Res. 67:161-171.

Heikkonen, H. 1998. Kasvatustiheyden vaikutus lihasikojen päiväkasvuun, sairastuvuuteen ja lääkityksen tarpeeseen. Syventävien opintojen tutkielma. Helsingin yliopisto, Eläinlääketieteellinen tiedekunta, Koteläinhygienia, Helsinki, $41 \mathrm{~s}$.

MMM. 1960. Laki helposti leviävien eläintautien vastustamisesta. L 488/60. Viitattu 27.11.2003. Saatavilla internetissä: http://www.mmm.fi/el/laki/d/d13.html.

MMM. 1980. Eläintautilaki. L55/80. Viitattu 27.11.2003. Saatavilla internetissä: http://www.finlex.fi/linkit/sd/19800055

Mangen, M-J.M. 2002. Economic welfare analysis of simulated control strategies for Classical Swine Fever epidemics. $\mathrm{PhD}$ thesis, Wageningen agricultural university. $186 \mathrm{p}$.

Pietola, K. \& Sévon-Aimonen, M-L. 2002. Eläinjalostus tuottaa lisäarvoa Suomen sikatalouteen. Julkaisussa: Maataloustieteen Päivät 2002 [verkkojulkaisu]. Suomen Maataloustieteellisen Seuran julkaisuja no 18. Toim. Anneli Hopponen. Viitattu 26.11.2003. Julkaistu 1.1.2002. Saatavilla Internetissä: http://www.agronet.fi/maataloustieteellinenseura/julkaisut/esit/50pietola.pdf. ISBN 951-9041-46-X.

Sevón-Aimonen, M.-L. 2001. The parameters of growth curve and composition of growth for Finnish pigs. In: Book of Abstracts of the 52nd Annual Meeting of the European Association for Animal Production: Book of abstracts 7. Budapest, Hungary 26-29 August 2001. Wageningen Pers, Wageningen., p. 290.

Tuovinen, V.K, Gröhn, Y.K., Straw, B.E. \& Boyd, R.D. 1992. Feeder unit environmental factors associated with partial carcass condemnations in market swine. Prev. Vet. Med. 12, 175-195. 